\title{
MRS Goes to Washington
}

One of the activities of the Materials Research Society's Public Affairs Committee has been to organize a visit in May to individuals in Washington, DC who are involved with support of scientific and engineering research. The MRS group, including Robert J. Nemanich (President), Ronald Gibala (Vice President), Julia M. Phillips (Chair of the Public Affairs Committee), and Ronald Kelley (MRS Office of Public Affairs), spent a day and a half in Washington.

Our goal in these visits was both to listen to concerns and issues and to express our backing for actions that will lead to continued support for scientific and engineering research. We spent time with Arthur Bienenstock of the Office of Science and Technology Policy (OSTP), Robert Trew of the Department of Defense (DoD), Thomas Weber of the National Science Foundation (NSF), Rep. Lynn Rivers (DMich.), and staff members of Sens. William H. Frist (R-Tenn.), Joseph I. Lieberman (DConn.), and Rick Santorum (R-Pa.).

Over the last two years MRS has played an important role in working with a group of societies (over 100) with a common interest in research. The focus of this group has been to call attention to the value for increasing federal support of civilian- and defense-related research. MRS has also supported this group with letters to Congress and the President (see MRS Bulletin, March 1998, page 29; December 1997, page 10; and May 1997, page 10). The wording from one of the previous letters gives insight into our approach and the issues, "The federal investment in scientific research is vital to four national goals: our military security, our economic competitiveness, our medical health, and our quality of life. Scientific disciplines are interdependent; therefore, weakness in any one of them will ultimately prevent us from reaching these goals. A strong foundation across the spectrum of research activities is imperative for our nation to meet the challenges of the next century. Doubling the nation's research budget during a 10-year period strikes a balance between nearterm fiscal goals and long-term economic growth and productivity," (from a letter sent to members of Congress and signed by the MRS President).

A key aspect of our reflections is the recognition of the interrelationship of the different scientific disciplines, which then necessitates broad support of all scientific disciplines. Certainly our MRS members recognize the importance of interdisciplinary research, and materials research in many ways serves as an example of the interrelationship of scientific disciplines.

In meeting with Bill Bonvillian and Peter Rooney, staff for Lieberman, we were updated on the issues related to the Gramm-Lieberman (S. 1305) legislation. They noted, as of May, that 17 senators have co-sponsored the bill, but 25 cosponsors are considered necessary to represent a significant consensus of the Senate. We expressed our support and appreciation for their efforts in this legislation. In our visit with Elizabeth Prostic, who is on the staff of the Science, Technology, and Space Subcommittee chaired by Frist, we were invited to comment on a proposed new piece of legislation (the Frist-Rockefeller bill, S. 2217) that has many of the attributes of the previous bill. We appreciated the opportunity to contribute at this formative stage of the legislation. Will Sears, staff for Santorum, noted in our meeting the Senator's awareness of technology and research activities in his home state. It was also evident to us that congressional representatives were particularly interested in hearing from members of their state or district.

We are all aware how military perspectives have changed over the past few years. Robert Trew, who now coordinates section 6.1 or basic research in DoD, described challenges in the future. Trew is an MRS member, and in our discussion he said that DoD has been one of the major supporters of U.S. university materials research. Legislation is pending that focuses on increasing the DoD research activities for the future.
The OSTP is in the Executive Branch of the government and serves to advise the President on issues of science and technology. It was a pleasure renewing our friendship with Bienenstock in his new position in OSTP. He is also an MRS member. We were joined by Beverly Hartline, assistant director of Physical and Engineering Sciences. Upon hearing their interesting perspective on science, we became aware of a broader range of issues facing science and technology. We were pleased to hear that materials is now recognized at OSTP as an important area of interdisciplinary research. Bienenstock and Hartline were also very supportive of the theme of the interrelationship of scientific disciplines and of the advantages of broad support of scientific research.

Several of us met with Tom Weber, director of the Division of Materials Research of the National Science Foundation. We expressed our appreciation for the division's past involvement in our meetings, and we are looking for more ways to build our relationship with NSF.

One thing that we were all struck by is the interest in personal anecdotes relating to the issues we support. On the day we met with Rivers she was involved with budget issues relating to research. She said how important it is for scientists to present a story which illuminates how scientific research will affect individual lives.

In all of these discussions, two things were evident: that Washington recognizes the importance of scientific and engineering research, and that many people are working hard to further this research. Our colleagues in government said that they do not hear from their constituents regarding scientific research very often. We encourage all of our members to make personal contacts to share your excitement of research discoveries, inventions, or innovations.

ROBERT J. NEMANICH RONALD GIBALA JULIA M. PHILLIPS RONALD KELLEY

For Advice on Effective Communication with the U.S. Congress and the White House, Access the Materials Research Society Public Affairs Website: http://www.mrs.org/pa/communication/

- How and why to build a relationship with your Legislator

- Pointers and Resources to help you get started 